\title{
Cidadania, poder local e controle do Estado
}

\author{
Angela Moulin Simôes Penalva Santos* \\ Eduardo Pereira Nogueira da Gama**
}

\begin{abstract}
Brazilian society is experiencing a population expansion within the context of decentralisation of public policies, from the central government to local institutions. Following this line of thought, in this article we analyse the public expenses in the Brazilian Federation in the period 1996-1998 in order to identify the institutions that have assumed the financial right of the citizens, as well as to estimate if there has been a transfer of responsibilities among federal institutions. The success of this process is related to the integrated performance of the external control from the public administration. In that sense, we also study the control exercised by Parliaments, Administrative Courts, Public Prosecution Offices and the Judicial Power beyond social control, taking into consideration their improvement and highlighting the control of the Public Prosecution Office as well as the control exercised by the popular councils.
\end{abstract}

Keyword: Decentralisation, external control from the administration, Public Prosecution Office, social control.

\section{Resumo}

A sociedade brasileira vem vivenciando a expansão de sua cidadania em um contexto de descentralização das políticas públicas, do governo central para as instâncias locais de poder. Nessa linha, o presente artigo analisa as despesas públicas na Federação Brasileira durante o período 1996-1998, buscando identificar quais instâncias governamentais têm assumido o financiamento dos direitos dos cidadãos, além de avaliar se houve transferência de responsabilidades entre instâncias federativas. Estando o êxito desse processo vinculado ao funcionamento integrado dos controles externos da Administração Pública, o presente artigo estuda também os controles exercidos pelos Parlamentos, Tribunais de Contas, Ministério Público e Poder Judiciario, além do controle social, tendo em vista o seu aprimoramento, destacando o controle exercido pelo Ministério Público e o controle social exercido por conselhos populares.

Palavras-chave: descentralização, controles externos da administração, ministério público, controle social.

\footnotetext{
" Universidade Estadual do Rio de Janeiro. Coreo-e: angelapenalva@terra.com.br

"* Universidade Estadual do Rio de Janeiro. Correo-e: edgama8@yahoo.com.br
} 


\section{Introdução $^{1}$}

O objetivo do artigo é a associação entre a proteção dos direitos dos cidadãos, o processo de descentralização e as formas de controle sobre o poder público. Trata-se de uma análise sobre como a sociedade brasileira vem vivenciando a expansão da sua cidadania em contexto de descentralização das políticas públicas.

A cidadania no Brasil foi significativamente expandida após a entrada em vigor da atual Constituição Federal, promulgada em 1988. A partir de então, os direitos constitucionais dos cidadãos passaram a incluir, além dos direitos civis, políticos e sociais, os coletivos e os difusos. Os primeiros (direitos civis e políticos) referem-se à primeira geração de direitos, o mais importante dos quais nas sociedades modernas é o relativo à segurança pública. Os direitos de segunda geração são aqueles chamados de "direitos sociais". O artigo $6^{\circ}$ da Constituição Federal do Brasil os define como abrangendo a educação, a saúde, o trabalho, a moradia, o lazer, a segurança, a previdência social, a proteção à maternidade e a assistência aos desamparados. Além desses, os cidadãos conquistaram os direitos difusos, também conhecidos por "direitos de terceira geração", sendo o relativo ao meio ambiente um dos mais relevantes dentre eles. Parte dos direitos sociais são apenas tutelados pelo Estado, como é o caso do direito ao trabalho, mas outros, como a previdência social, são providos diretamente pelo Estado. Ambos os casos, todavia, exigem, menos ou mais, o aporte de recursos públicos.

$\mathrm{O}$ atendimento a uma agenda ampliada de cidadania constitui um grande desafio ao poder público dado o contexto de globalização, limitando a atuação do Estado. Como é por demais sabido, a crescente interdependência da economia mundial ao longo das duas últimas décadas resultou numa progressiva perda de capacidade do Estado em formular e implementar políticas que desafiem a ordem internacional. Assim, as políticas de maior alcance no que tange à produção e emprego, as políticas monetária, fiscal e cambial, tornam-se prisioneiras de uma agenda internacional sobre a qual governos de países como o Brasil têm escassa

${ }^{1}$ Agradecemos ao estagiário Leonardo Pereira Cassol pela organização dos dados nas tabelas referentes aos gastos do poder público; a Cláudia Alves de Oliveira e a Maria Guadalupe Piragibe da Fonseca, pelos comentários que contribuíram para a elucidação de alguns pontos do artigo, eximindo-lhes todavia da responsabilidade sobre o conteúdo do texto e as informações divulgadas. Esse artigo foi apresentado no VII Seminario de la Red Iberoamericana de Investigadores de Globalización y Territorio, Camagüey, Cuba, novembro de 2002. 
possibilidade de interferir. Após 50 anos de forte intervencionismo estatal (1930-1980), o Estado brasileiro vê limitado em grande medida seu poder de induzir o desenvolvimento e manter-se como sujeito do processo de modernização das estruturas sociais, políticas e econômicas.

Esse constrangimento a que se submete o Estado Nacional, e que não é exclusivo do caso brasileiro, suscitou o debate sobre a necessidade da "reforma do Estado" urbi et orbi. As principais faces dessa reforma foram o processo de privatização do setor produtivo estatal e a descentralização das responsabilidades do governo federal para as instâncias locais de poder. A descentralização passou a ser defendida como uma estratégia para lograr melhor gerenciamento do poder público, uma vez que é o governo local que tem maior capacidade de alocar eficazmente os bens públicos cujos benefícios sejam espacialmente localizados. Outro argumento importante é que o fornecimento de bens públicos pelos governos locais proporciona maior flexibilidade e melhor adaptação dos investimentos públicos às preferências e necessidades da população. Ademais, o fato de o governo municipal atuar sobre um universo menor de cidadãos favorece a maior participação da população na formulação das políticas públicas, democratizando as estruturas de poder. Essa, por sua vez, "territorializa" a demanda por cidadania, de "baixo para cima", conferindo legitimidade ao poder público.

A descentralização constitui uma inovação na estrutura do poder político, uma estratégia para conferir legitimidade ao poder público. O êxito desse processo depende, entretanto, da existência de instrumentos de controle externo do Estado, seja pela disseminação da cultura de participação popular, seja pela criação de instituições voltadas para esse fim. No Brasil, a Administração Pública está sujeita a um controle externo exercido pelo Poder Legislativo, com o auxílio de Tribunais de Contas, encarregados da fiscalização contábil, financeira, orçamentária, operacional e patrimonial de todas as entidades administrativas e de todos os projetos desenvolvidos por entidades privadas com recursos públicos. Além dessa, a Administração Pública também está sujeita a outra forma de controle externo: trata-se do controle exercido pelo Poder Judiciário, sob provocação do Ministério Público, dos cidadãos e entidades coletivas. Pode-se ainda mencionar o controle externo que é feito diretamente pelo Ministério Público, independentemente de provocação ao Poder Judiciário, além do controle social, exercido diretamente pelas entidades civis e cida- 
dãos, sempre que estes ajudam a planejar e a fiscalizar a aplicação dos recursos públicos e cobram de seus representantes políticos uma gestão responsável da res publica.

O objetivo de associar esses fenômenos da cidadania expandida, descentralização da administração pública e controle externo do Estado será realizado mediante: i) levantamento de dados relacionados à estrutura das despesas públicas, buscando evidências a respeito de qual instância governamental tem assumido a responsabilidade pela tutela ou financiamento dos distintos direitos dos cidadãos brasileiros, além de avaliar se houve, no período considerado (1996-1998), transferência de responsabilidades entre instâncias de governo; e ii) estudo sobre as distintas formas de controle externo do Estado, dentre as quais destacam-se o exercido pelo Ministério Público, por se tratar de Instituição autônoma, cujos membros têm alto grau de independência funcional e um amplo espectro de atribuições no controle do poder público; e o controle social, exercido mediante a instituição de conselhos populares.

\section{Descentralização e estrutura das despesas públicas}

Durante o período 1930-1980, o Brasil experimentou uma mudança extraordinária na sua estrutura social, produtiva, demográfica e política. Até a Revolução de 1930 -e da Grande Depressão de 1929-, o país era essencialmente rural e dependente das agroexportações. A partir daí, houve intenso processo de industrialização e um outro, ainda mais acelerado, de urbanização da população. Em 1940, menos de uma terça parte da população (31,2\%) vivia em áreas urbanas, mas, em 1980, esse índice já havia alcançado dois terços.

Esse crescimento demográfico está associado às transformações na estrutura produtiva, com a indústria passando a contribuir com $40.56 \%$ do PIB, em 1980, enquanto que a agropecuária declinava sua participação a apenas $10.2 \%$. A superação da condição de país agrícola levou à expansão do PIB per capita de $\mathrm{R} \$ 637.00^{2} \mathrm{em}$ $1947^{3}$ para $\mathrm{R} \$ 2,686.00$, em 1980. A partir desse ano, e até 1996, esse valor variou pouco, mas sempre mantendo um valor inferior ao vigente em 1996, tendo somente voltado a crescer a taxas

\footnotetext{
${ }^{2}$ A preços de 2001, segundo a fonte Instituto de Pesquisa Econômica Aplicada (IPEADATA).

${ }^{3}$ O cálculo do PIB foi iniciado em 1947.
} 
modestíssimas, em 1997. Em 2001, o PIB per capita do país era de $\mathrm{R}$ \$ 2.922,00, apenas 8,8\% superior àquele de 1980 .

No período 1930-1980, a expansão econômica e a modernização das estruturas sociais, políticas, demográficas e econômica esteve associada à intervenção estatal num contexto de afirmação das políticas keynesianas, de ampliação de direitos sociais e da concepção cepalina segundo a qual a industrialização era considerada instrumento de superação do subdesenvolvimento. A implementação exitosa de dois planos de desenvolvimento, o Plano de Metas (1956-1961) e o II PND (1974-79) permitiram que praticamente se completasse a estrutura industrial no Brasil, elevando o país à condição de potência regional. Nos dois planos, o investimento público do governo federal foi o mecanismo que sustentou o êxito daquelas políticas, o que teria permitido a 'marcha forçada' da economia brasileira mesmo após a desaceleração do crescimento econômico, na segunda metade da década de 1970. Aquele período foi, enfim, marcado pela constituição do país como uma nação, segundo o eminente economista Celso Furtado, por ter articulado as distintas regiões do país em torno do projeto nacional de industrialização.

Ao longo das décadas de 1980 e 1990, a taxa de investimentos caiu significativamente, resultado da crise econômica, mas, em particular, em função da incapacidade do governo federal sustentar as taxas de investimento que tinha realizado principalmente no período de 1950 a 1970. Em 1980, a taxa de investimentos ${ }^{4}$ foi cerca de $24 \%$, declinando em seguida até atingir o nível mais baixo, correspondente a cerca de 14\%, em 1992. Após a estabilização monetária de 1995, mediante a implantação do Plano Real, houve uma pequena melhora naquela taxa, mas esta tem se mantido em torno de 16\% do PIB. Esse desempenho está associado à retração do setor público. Segundo o Instituto Brasileiro de Geografia e Estatística-IBGE-, (Contas Nacionais do Brasil) o investimento público declinou significativamente em proporção à taxa de investimento global na economia brasileira. A tabela 1 apresenta a composição dos investimentos, segundo a origem do capital.

${ }^{4}$ Como percentagem do PIB e a preços de 1980, segundo a fonte IPEADATA. 


\section{Tabela 1}

Taxa de investimento, por origem do capital 1996-2000

\begin{tabular}{|l|r|r|r|r|r|}
\hline \multicolumn{1}{|c|}{ Investimento } & \multicolumn{1}{c|}{1996} & \multicolumn{1}{c|}{1997} & \multicolumn{1}{c|}{1998} & \multicolumn{1}{c|}{1999} & \multicolumn{1}{c|}{$\mathbf{2 0 0 0}$} \\
\hline Investimento & $162,953\left(^{*}\right)$ & $187,187\left(^{*}\right)$ & $193,056\left(^{*}\right)$ & $195,401\left(^{*}\right)$ & \multicolumn{2}{c|}{$236,169\left(^{*}\right)$} \\
\hline Setor público & $22.0 \%$ & $20.9 \%$ & $20.8 \%$ & $15.0 \%$ & $13.5 \%$ \\
\hline Adm. pública & $11.0 \%$ & $9.2 \%$ & $13.3 \%$ & $8.6 \%$ & $8.9 \%$ \\
\hline Empresas públicas & $11.0 \%$ & $11.7 \%$ & $7.5 \%$ & $6.4 \%$ & $4.6 \%$ \\
\hline Setor privado & $78.0 \%$ & $79.1 \%$ & $79.2 \%$ & $85.0 \%$ & $86.5 \%$ \\
\hline
\end{tabular}

Fonte: IBGE, Diretoria de Pesquisas, Departamento de Contas Nacionais.

(*) Valor em Rs 1.000.000

Os dados acima apontam um declínio da contribuição do Setor Público para o nível dos investimentos na economia brasileira. Cabe destacar que esse declínio é mais significativo no âmbito das Empresas Públicas, mais do que na Administração Pública, devido ao aprofundamento do processo de privatização do setor produtivo estatal, uma das faces da "Reforma do Estado" ocorrida ao longo da década de 1990. É dentro desse contexto que a descentralização assume uma importância ímpar, como a outra face da "Reforma do Estado", no sentido de busca por relegitimação.

A pesquisa "Despesas Públicas Por Funções 1996-1998", do IBGE, consolida a estrutura das despesas públicas segundo os três níveis da Administração Púbica e permite analisar a contribuição da União, Estados e municípios para os investimentos públicos, ${ }^{5}$ além de fornecer indicadores sobre as despesas nos setores que correspondem aos direitos dos cidadãos brasileiros, conforme expresso na Constituição Federal de 1988 (tabela 2).

Os dados acima nos permitem destacar dois fenômenos. O primeiro, refere-se ao declínio das despesas não-financeiras como parte das despesas da União, o que se traduz num avanço das despesas financeiras, as quais incluem juros, amortizações e inversões financeiras. Em 1998, esses itens das despesas financeiras corresponderam a respectivamente $7.53 \%, 41.22 \%$ e $13.39 \%$ das despesas totais da União. Portanto, a incapacidade de sustentar investimentos é decorrente do crescente comprometimento do Governo Federal com a dívida pública. Nos níveis estaduais e

${ }^{5}$ Os dados sobre municípios cobrem apenas 245 dos 5,567 municípios brasileiros. Os municípios incluídos na pesquisa são capitais estaduais e municípios localizados em regiões metropolitanas, além de alguns cujas elevadas participações no PIB estadual os levaram a ser incluídos na amostra. A importância da amostra pode ser inferida a partir do percentual de população dos municípios incluídos em relação à população dos estados da Região Sudeste: no Espírito Santo, a população dos municípios incluídos na amostra correspondeu a 48.8\%, em Minas Gerais foi de 30.4\%, no Rio de Janeiro de $79.4 \%$ e em São Paulo igual a 53,5\%. 


\section{Tabela 2}

Despesas Públicas: Participação percentual das despesas nãofinanceiras e despesas com capital (investimentos) nas despesas totais de união, estados e municípios

\begin{tabular}{|c|c|c|c|}
\hline $\begin{array}{c}\text { Setor } \\
\text { Público }\end{array}$ & Ano & Despesas não-financeiras \% & Despesas com capital \% \\
\hline \multirow{4}{*}{ União } & 1996 & 50.07 & 1.30 \\
\cline { 2 - 4 } & 1997 & 42.89 & 1.19 \\
\cline { 2 - 4 } & 1998 & 37.77 & 0.96 \\
\hline \multirow{3}{*}{ Estados } & 1996 & 84.63 & 5.10 \\
\cline { 2 - 4 } & 1997 & 74.99 & 5.90 \\
\cline { 2 - 4 } & 1998 & 79.33 & 8.80 \\
\hline \multirow{3}{*}{ Municípios } & 1996 & 91.02 & 19.10 \\
\cline { 2 - 4 } & 1997 & 88.80 & 10.60 \\
\cline { 2 - 4 } & 1998 & 88.80 & 9.46 \\
\hline
\end{tabular}

Fonte: IBGE: Despesas Públicas por Funções 1996-1998.

municipais, há maior controle sobre o processo de endividamento, inclusive por parte da União que, até a edição da Lei de Responsabilidade Fiscal em maio de 2000, vinha assumindo parte das dívidas das instâncias subnacionais de governo, uma vez que era a avalista, quando não a credora, daquelas dívidas. De todo modo, causa preocupação a trajetória ascendente do comprometimento do dispêndio público com as despesas relacionadas ao endividamento do Estado brasileiro, particularmente da União.

O segundo fenômeno a ser destacado refere-se ao 'ciclo político' do gasto público. O maior percentual de investimento municipal foi observado em 1996, ano de eleições de prefeitos. Quanto aos estados, o maior percentual de despesas com investimentos ocorreu justamente em 1998, ano de eleições de governadores. Os 'investimentos eleitoreiros' poderão ser limitados após a vigência da Lei de Responsabilidade Fiscal, dado o impedimento de comprometer despesas que não podem ser pagas no mesmo mandato ou sem reserva de receitas para enfrentar o fluxo de despesas que ficarem para outro mandato governamental. De todo modo, a evidência do "ciclo político" indica que as eleições constituem poderoso instrumento de alocação da despesa pública em favor de investimentos que, mesmo sem informações sobre a natureza deles, supõe-se que atendam a demandas da população.

O maior comprometimento das despesas da União com a dívida e sua incapacidade de manter níveis de investimentos são 
percebidos como impactos da globalização financeira, traduzida pelo aumento dos investimentos externos diretos e, principalmente, pelos fluxos de capitais especulativos, aplicados em mercados voláteis. O difícil enfrentamento na esfera nacional desse fenômeno internacional torna o setor público mais vulnerável, enfrentando crises de legitimidade no âmbito nacional. Cresce, portanto, a tendência de transferir aos níveis subnacionais de governo antigos compromissos, em particular, aqueles que se referem a direitos já conquistados pelos cidadãos e que estão expressos na Constituição Federal. As tabelas 3 e 4 apresentam os gastos públicos segundo níveis de governo em setores selecionados, aqueles correspondentes aos direitos dos cidadãos.

\section{Tabela 3}

Despesas públicas: participação percentual de setores selecionados nas despesas da União, dos estados e municípios (em \%)

\begin{tabular}{|l|r|r|r|r|r|r|r|r|r|}
\hline \multirow{2}{*}{ Setores / Ano } & \multicolumn{3}{|c|}{ União } & \multicolumn{3}{c|}{ Estados } & \multicolumn{3}{c|}{ Municípios } \\
\cline { 2 - 11 } & 1996 & 1997 & 1998 & 1996 & 1997 & 1998 & 1996 & 1997 & 1998 \\
\hline Habitação & 0.10 & 0.09 & 0.05 & 0.77 & 0.74 & 0.60 & 1.04 & 1.35 & 1.13 \\
\hline Saúde & 4.42 & 3.83 & 3.01 & 5.78 & 5.90 & 5.73 & 14.12 & 15.69 & 16.77 \\
\hline Desenvolvimento urbano & 0.09 & 0.10 & 0.06 & 0.46 & 0.62 & 0.92 & 10.43 & 8.49 & 7.83 \\
\hline Educação & 2.57 & 2.27 & 1.94 & 13.97 & 12.02 & 13.07 & 13.65 & 14.57 & 16.27 \\
\hline Saneamento & 0.16 & 0.20 & 0.10 & 0.49 & 0.67 & 0.73 & 9.13 & 8.49 & 7.18 \\
\hline Proteção social & 27.90 & 23.40 & 21.10 & 19.40 & 16.50 & 17.80 & 10.60 & 13.40 & 13.90 \\
\hline Ordem e segurança pública & 11.00 & 10.50 & 11.30 & 12.00 & 10.70 & 10.50 & 0.40 & 0.50 & 0.60 \\
\hline
\end{tabular}

Fonte: IBGE: Despesas Públicas por Funções 1996-1998.

Tabela 4

Despesas públicas: participação percentual de cada nível de governo na despesa total do poder público em setores selecionados (em \%)

\begin{tabular}{|l|r|r|r|r|r|r|r|r|r|}
\hline \multirow{2}{*}{ Setores / Ano } & \multicolumn{3}{|c|}{ União } & \multicolumn{3}{c|}{ Estados } & \multicolumn{3}{c|}{ Municípios } \\
\cline { 2 - 11 } & 1996 & 1997 & 1998 & 1996 & 1997 & 1998 & 1996 & 1997 & 1998 \\
\hline Habitação & 21.6 & 21.3 & 18.1 & 59.3 & 57.5 & 56.1 & 19.1 & 21.2 & 25.8 \\
\hline Saúde & 57.1 & 56.6 & 52.7 & 27.1 & 28.3 & 27.6 & 15.8 & 15.1 & 19.7 \\
\hline Desenvolvimento urbano & 7.4 & 11.2 & 7.3 & 14.3 & 23.6 & 30.3 & 78.3 & 65.2 & 62.4 \\
\hline Educação & 29.1 & 31.8 & 29.2 & 57.5 & 54.9 & 54.3 & 13.4 & 13.3 & 16.5 \\
\hline Saneamento & 14.5 & 20.7 & 13.2 & 15.7 & 22.3 & 25.7 & 69.8 & 57.0 & 61.1 \\
\hline Proteção social & 77.8 & 78.9 & 78.3 & 19.6 & 18.1 & 18.2 & 2.6 & 3.0 & 3.5 \\
\hline Ordem e segurança pública & 26.6 & 28.7 & 29.1 & 72.8 & 70.6 & 70.0 & 0.6 & 0.7 & 0.9 \\
\hline
\end{tabular}

Fonte: IBGE: Despesas Públicas por Funções 1996-1998. 
Habitação, saúde e educação são direitos sociais, conforme disposto no artigo $6^{\circ}$ da Constituição Federal. Desenvolvimento urbano e saneamento foram incluídos por constituírem setores nos quais o gasto público é fundamental para permitir melhores condições de vida e terem impacto positivo no cálculo do Índice de Desenvolvimento Humano. O setor proteção social inclui os subsetores trabalho, assistência social e previdência social, todos são direitos sociais. No setor Ordem e Segurança Pública, estão incluídos subsetores correspondentes a direitos civis, casos do policiamento militar, da defesa civil e do judiciário.

Conforme indicam os dados, a União compromete percentuais significativos de suas despesas com os setores relativos a proteção social e ordem e segurança pública. O primeiro refere-se a responsabilidade tipicamente do governo federal, conforme expresso na Constituição Federal, por incluir a previdência social, item mais significativo das despesas não-financeiras dos governos urbi et orbi. ${ }^{6}$ Dos gastos totais efetuados nesse setor, a União contribui com mais de 75\%. Já o segundo, refere-se a um setor da competência principal dos governos estaduais, os quais alocam pelo menos $70 \%$ dos gastos nesse setor dado os impactos do judiciário e do policiamento militar. Além desses dois setores, a União é responsável pela alocação de parcela importante de seu orçamento nos setores de saúde e educação, mas numa proporção menos significativa em relação àqueles dois setores anteriormente mencionados.

$\mathrm{Na}$ esfera dos governos estaduais, como na União, o setor proteção social é o principal comprometimento das despesas estaduais, ainda que sua participação nas despesas totais do setor não alcancem 20\%. O segundo setor mais importante na alocação dos gastos estaduais é o de educação, em cujo gasto total, os estados respondem por cerca de $55 \%$, a União com cerca de $30 \%$ e os municípios com apenas de 13 a 17\%. Apesar do claro predomínio da esfera estadual, é significativa a elevação da participação dos governos municipais em educação. Além desses dois setores, os governos estaduais são os principais responsáveis pelos gastos em habitação. Os Estados são responsáveis por mais de $50 \%$ dos dispêndios públicos nesse setor, observando-se uma participação declinante da União e, inversamente, um aumento da participação dos gastos municipais, os quais já correspondem

${ }^{6}$ Em seu estudo comparativo sobre federalismo fiscal, Miguel Asencio analisa a estrutura das finanças públicas considerando a presença ou a ausência do orçamento da previdência social, que, em função de sua magnitude pode mascarar o processo de descentralização nas federações por ele analisada (Asensio, 2000). 
a um quarto dos gastos em habitação. Pode-se inferir desse resultado que os municípios devam estar assumindo novas responsabilidades no atendimento de demandas que representam direitos dos cidadãos em face da retração dos dois níveis governamentais superiores.

Entre os governos municipais, os maiores comprometimentos das despesas referem-se aos setores saúde e educação. Trata-se dos dois setores nos quais houve maior avanço no processo de descentralização na prestação dos serviços, com a União alocando de 2 a 4\% do seu orçamento global nesses setores. Apesar de percentuais baixos, o dispêndio do governo federal na saúde corresponde a mais de $50 \%$ do gasto no setor, sendo, portanto, seu principal financiador. No setor da educação, são os governos estaduais que financiam mais de $50 \%$ dos gastos públicos, ficando a União responsável por algo como $30 \%$.

Ainda no que tange aos municípios, cabe destacar a trajetória ascendente da participação do setor proteção social nos gastos públicos. Apesar dos municípios financiarem apenas cerca de 3\% dos recursos totais do setor, esses valores vêm crescendo e consumindo uma parcela também crescente do orçamento municipal em função da elevação das despesas com o subsetor assistência social.

Os governos municipais alocam parcelas significativas, porém menores que nos setores acima mencionados, em desenvolvimento urbano e saneamento. Em ambos, houve redução dos percentuais em relação às despesas totais dos Municípios. No entanto, correspondem claramente a responsabilidades municipais, dado que as prefeituras participam com valores superiores a $60 \%$ dos gastos totais nesses setores. Nos dois casos, os governos estaduais aumentaram significativamente sua participação no financiamento, verificando-se uma estagnação no financiamento da União. Esse crescente financiamento na esfera estadual pode estar relacionado com o anteriormente aludido 'ciclo político', dado que 1998 foi ano de eleições para governadores. De todo modo, o financiamento decrescente em saneamento, cujos investimentos estão praticamente paralisados, pode estar relacionado com os impasses sobre a que esfera de governo cabe a responsabilidade de regular o setor: Os estados, como já vinham fazendo através de empresas estatais, ou aos municípios, em conformidade com a autonomia municipal conquistada em 1988?

Cabe finalizar, destacando o aumento da contribuição dos municípios em quase todos os setores considerados. Apenas naque- 
les dois onde o financiamento era responsabilidade dos governos municipais, desenvolvimento urbano e saneamento, houve diminuição da contribuição dos municípios. Nos demais, houve transferência de responsabilidade no financiamento para os governos municipais, num processo de descentralização claramente definido. Esse aumento de encargos na esfera dos governos locais suscita grande preocupação quanto à responsabilidade dos executivos municipais em assumirem novas funções, gerirem maiores orçamentos, mantendo, de um lado, comportamento fiscalmente responsável, e, de outro, atendendo a demandas crescentes em respeito aos direitos dos cidadãos.

\section{Controle externo do Estado}

O processo de transferência de responsabilidades desde a União até os governos estaduais e, principalmente, municipais, vem sendo acompanhado de novos e maiores desafios no que respeita ao controle do poder público. Apesar de o controle interno da administração pública ser essencial, até para auxiliar as atividades de controle externo, é nestas últimas que existe a possibilidade de um controle mais isento, por não estarem vinculadas à mesma esfera de poder da entidade investigada.

Entre as formas de controle externo das unidades administrativas dos vários entes federativos brasileiros, encontram-se: i) o controle parlamentar direto; ii) o controle pelos Tribunais de Contas; iii) o controle pelo Poder Judiciário; iv) o controle pelo Ministério Público, que merecerá atenção especial neste estudo; v) o controle social, isto é, efetivado diretamente pelos cidadãos e entidades coletivas.

\subsection{O controle parlamentar direto}

O controle parlamentar direto é o que existe, por exemplo, quando o Poder Legislativo (na esfera federal, o Congresso) julga anualmente as contas prestadas pelo Chefe do Poder Executivo (na esfera federal, o Presidente da República), e aprecia os relatórios sobre a execução dos programas de governo. Apesar de o Poder Legislativo ter uma competência geral para fiscalizar qualquer ato da Administração Pública, direta ou indireta, tais atos de fiscalização acabam se restringindo ao julgamento anual das contas do Chefe do Executivo (pois que este encargo é claro no texto constitucional), que em regra assume caráter mais político 
do que técnico, e às investigações eventuais promovidas por Comissões Parlamentares de Inquérito, com o objetivo de apurar fato determinado, e não de investigar rotineiramente (isto é independentemente de provocação ou notícia de irregularidade).

\subsection{O controle exercido pelos Tribunais de Contas}

Cabe na verdade aos Tribunais de Contas a investigação quotidiana sobre o emprego dos recursos públicos pela grande maioria das unidades administrativas e por quaisquer particulares. Com exceção das contas pessoais do Chefe do Poder Executivo e das contas do Presidente do Poder Legislativo, que são julgadas pelo plenário do Órgão Legislativo competente, todas as demais contas acerca da aplicação de recursos públicos por unidades administrativas da administração direta e indireta, bem como por cidadãos e entidades privadas, são julgadas pelas Cortes de Contas, sem qualquer interferência do Poder Legislativo no processo decisório. Assim, por exemplo, se o Tribunal de Contas da União (TCU) reprova as contas apresentadas pelo Ministério da Educação, não cabe ao Poder Legislativo modificar tal decisão, pois não dispõe de tal competência.

O julgamento exercido pelas Cortes de Contas abrange os aspectos contábil, financeiro, orçamentário, patrimonial e operacional. Controle contábil é o que se materializa sobre o registro administrativo (escrituração contábil) de todas as operações de natureza orçamentária, financeira e patrimonial, durante o exercício financeiro. É esse registro que possibilita à administração tomar decisões estratégicas sem comprometer suas receitas e elaborar sua prestação de contas. Controle financeiro é o que se exerce sobre a movimentação financeira realizada no exercício, englobando a receita e a despesa orçamentárias, bem como os recebimentos e pagamentos de natureza extra-orçamentária, conjugados com os saldos em espécie (positivos ou negativos) provenientes do exercício anterior, e os que se transferem para o exercício seguinte. Controle orçamentário é o que diz respeito à verificação da obediência ao princípio da legalidade orçamentária, pois em regra as despesas públicas só podem ser efetuadas se legalmente autorizadas. Já o controle patrimonial diz respeito à averiguação da guarda e administração dos bens (especialmente os de caráter permanente) que compõem o patrimônio público e integram o balanço patrimonial da entidade administrativa fiscalizada (Fernandes, 1995: 199-200). 
Dentre os controles exercidos pelos Tribunais de Contas, todavia, merece destaque o controle operacional, inovação introduzida pela Constituição Federal de 1988, e que tem como objetivos: i) analisar o planejamento, a organização e os sistemas internos de controle administrativo; ii) avaliar a eficiência e a economicidade com que são utilizados os recursos humanos, materiais e financeiros; iii) avaliar o resultado das operações realizadas em relação aos objetivos pretendidos. O controle operacional representa um salto de qualidade na fiscalização das atividades administrativas, pois que as outras formas de controle em regra são exercitadas a posteriori (depois que os atos já foram praticados) e têm caráter meramente formal, limitando-se a verificar se os procedimentos da administração foram praticados de acordo com as normas da contabilidade orçamentária, financeira e patrimonial. O controle operacional vem justamente atender a uma maior demanda social por eficiência administrativa, pois não só possibilita um controle da administração pública durante a execução dos programas de governo, como também possibilita que haja um controle substancial sobre tal execução, sempre que ela estiver descumprindo as metas ou a ordem de prioridades estabelecidas nas leis orçamentárias (Fernandes, 1995: 200-201). Por exemplo, cabe aos Tribunais de Contas investigar se a União está aplicando anualmente no mínimo 18\%, e os Estados, o Distrito Federal e os Municípios, $25 \%$ da receita resultante de impostos (compreendida a resultante de transferências) na manutenção e desenvolvimento do ensino (Constitução Federal, 1988: art. 212).

Não raro as Cortes de Contas têm rejeitado a prestação de contas de inúmeras unidades administrativas, seja pela falta de um sistema de controle interno apropriado, seja pela utilização de recursos públicos de maneira indevida, como no caso do superfaturamento de obras e serviços, ou no caso de sua execução com baixa qualidade. O Controle operacional, todavia, muitas vezes não aparece nas decisões dos Tribunais de Contas, pois é feito em boa parte pela equipe técnica das Cortes de Contas (engenheiros, assessores jurídicos, contadores, economistas, administradores e outros profissionais), e durante a execução dos projetos administrativos. Sendo as irregularidades sanadas, acabam não sendo consideradas no momento posterior em que as contas são julgadas.

Assumem os Tribunais de Contas, portanto, importante papel no controle da administração pública, mormente no que tange à fiscalização da aplicação de recursos em políticas públicas que 
efetivam os direitos do cidadão. No caso de recursos que são repassados pela União às demais esferas federativas em áreas como assistência social, saúde e educação, além de outros, repassados por convênio, o Tribunal de Contas da União tem a atribuição de fiscalizar, em regra, o repasse dos recursos pelo Órgão competente da União; os Tribunais de Contas dos Estados ou municípios da respectiva unidade que recebeu os recursos são responsáveis pela fiscalização dos atos de gestão dos recursos repassados (Fernandes, 1999: 79-107).

De se lembrar ainda que cabe aos Tribunais de Contas a fiscalização do cumprimento, em todos os níveis federativos, das normas de gestão de recursos previstas na recente lei de responsabilidade fiscal, que prevêem, por exemplo, limites para a realização de operações de crédito, despesas de pessoal, dívidas consolidadas e mobiliárias, bem como para a destinação de recursos obtidos com a alienação de ativos, em relação aos diversos órgãos dos três poderes e ao Ministério Público. Um dos objetivos maiores da lei de responsabilidade fiscal é justamente impedir o descontrole nos gastos do poder público e possibilitar a existência de recursos públicos para que sejam implementadas as políticas públicas que efetivam os direitos do cidadão. Esse objetivo, portanto, passa a ser fiscalizado pelos Tribunais de Contas.

A importância dos Tribunais de Contas é tamanha que hoje parte da doutrina os reconhece como órgãos constitucionais autônomos (Medauar, 2002: 473; Meirelles, 2002: 670; Moreira Neto, 2001: 11-22; Brito, 2002: 177-187), isto é, não vinculados a nenhum dos três poderes tradicionais, uma vez que:

- Sua organização e suas funções têm sede constitucional, sendo muitas destas exercidas somente pelo Tribunal, independentemente da atuação do Poder Legislativo;

- Possuem autonomia administrativa em relação aos demais Poderes, por terem quadro próprio de pessoal e as atribuições de autonomia administrativa que são conferidas aos Tribunais, como eleger seus órgãos diretivos; elaborar seus regimentos internos, organizando as funções de seus órgãos e serviços administrativos; velar pelo exercício da atividade correicional respectiva; prover, por concurso público, os cargos necessários ao exercício de suas funções. (Constitução Federal, 1988: arts. 73 e 96, c/c art. 75); 
- Seus membros têm independência funcional em relação a qualquer autoridade pública, uma vez que têm as mesmas garantias, prerrogativas, impedimentos, vencimentos e vantagens dos membros do Poder Judiciário (Constitução Federal, 1988: art. $73 \mathbb{S} 3^{\circ}, \mathrm{c} / \mathrm{c}$ art. 75$)$;

- A Constituição não fica expressamente sua autonomia financeira, isto é, a capacidade de elaborar a proposta orçamentária para seus serviços e o poder de gerenciar/ aplicar da melhor forma os recursos públicos que lhe são conferidos, mas ela está garantida em parte na lei orgânica do TCU, quanto à gestão dos recursos pelo Presidente da Corte;

- As decisões das Cortes de Contas são definitivas, com relação às avaliações sobre a gestão financeira, orçamentária, patrimonial, contábil e operacional do Poder Público. Tais decisões só podem ser modificadas, em regra, pelas próprias Cortes que as proferiram. O Poder Judiciário só pode interferir em casos excepcionais, para sanar ilegalidades manifestas e assegurar o respeito aos direitos subjetivos das pessoas investigadas (como o direito à ampla defesa);

- As Cortes de Contas têm competência constitucional para aplicar aos responsáveis sanções como ressarcimento integral do prejuízo causado ao patrimônio público, bem como multa proporcional ao dano (Constitução Federal, 1988: art. 71, vIII e $\mathbb{S} 3^{\circ}$ ).

Entendemos, contudo, que o fato de serem autônomos os Tribunais de Contas não é incompatível com a integração de tais Cortes ao Poder Legislativo, a uma, pois as normas constitucionais sobre tais Cortes estão junto às demais normas que regem o Poder Legislativo; a duas, pois a Constituição prevê tanto para o Poder Legislativo quanto para os Tribunais de Contas a competência de julgar as contas da Administração Pública, todavia atribuindo para tais Órgãos espectros de análise diferentes, no que tange às contas pessoais do Chefe do Executivo ou às contas das entidades administrativas. Além disso, em ambos os julgamentos haverá um juízo de legitimidade, isto é, se a gestão administrativa foi realizada em prol da sociedade, tendo como parâmetros a Constituição, as leis e os orçamentos. Esse juízo de legitimidade, em uma democracia, como se sabe, está intimamente ligado ao povo, que é representado pelo Legislativo. Por isso, não é deméri- 
to nenhum para os Tribunais de Contas que façam parte do Poder Legislativo, mas antes essa é uma afirmação que pode oxigenar a imagem do Poder Legislativo junto à sociedade. Para que isso seja possível, todavia, deve-se reconhecer e aprimorar a autonomia institucional das Cortes de Contas, para que possam desempenhar bem suas funções de controle externo de eficiência da administração pública.

Nesse sentido, um complicador para a boa atuação dos Tribunais de Contas tem sido a indicação 'política' de seus membros. Dois terços dos membros de tais Cortes são escolhidos pelo Poder Legislativo (na esfera federal, o Congresso Nacional), e um terço pelo Poder Executivo, com aprovação do Legislativo (na esfera federal, o Senado). Apesar de a Constituição Federal exigir qualificação técnica ('notórios conhecimentos jurídicos, contábeis, econômicos e financeiros ou de administração pública'), experiência ('mais de dez anos de exercício de função ou de efetiva atividade profissional que exija os conhecimentos mencionados'), idoneidade moral e reputação ilibada como requisitos a guiar a escolha dos julgadores de contas, em muitos casos, as nomeações têm sido motivadas por interesses político-partidários, e não pela qualificação do nomeado, o que tem prejudicado uma atuação mais competente e isenta na cúpula dos Tribunais de Contas. ${ }^{7}$ Embora o corpo técnico de tais Cortes faça em regra a sua parte, nem sempre o que ele recomenda é considerado pelos julgadores de contas, que algumas vezes decidem de acordo com os interesses partidários do Chefe do Executivo ou de grupos na Casa Legislativa, pois que estes dois órgãos fazem as nomeações dos membros de tais Cortes. ${ }^{8}$

${ }^{7}$ Conforme informou a Revista Veja (2002: 36-39), dos 229 conselheiros estaduais então existentes no Brasil, 118 eram ex-deputados, ex-senadores, ex-prefeitos e exvereadores, o que indica como os Tribunais de Contas acabam sendo dominados pelos políticos. Havia então duas dezenas de projetos tramitando no Congresso sobre os Tribunais de Contas, sendo que sete buscavam mudar os critérios de nomeação, mas nenhum deles conseguia avançar.

${ }^{8}$ A Revista Veja (2002: 36-39) noticiou inúmeros ilícitos em Tribunais de Contas brasileiros, como o caso do desvio de verbas públicas federais (169 milhões de reais) para a construção do prédio do Tribunal Regional do Trabalho do Estado de São Paulo. Os técnicos do Tribunal de Contas da União (ТСU) constataram irregularidades graves ainda em 1992, logo no início da obra, mas só em 1998 ela foi embargada pelo TCu, por pressões do Ministério Público e da Comissão Parlamentar de Inquérito do Poder Judiciário. Durante seis anos, o processo passou por dois ministros do TCU, o primeiro nada tendo feito e o segundo tendo mandado a obra seguir, argumentando que havia sido gasto muito dinheiro e que o prejuízo seria menor se a obra fosse concluída. Os outros casos relatados pela Revista referem-se a práticas de nepotismo, desvio e apropriação de verbas públicas, superfaturamento de produtos e outras ilegalidades atribuíveis a alguns membros dos Tribunais de Contas dos Estados de Mato Grosso do Sul, Amapá, Acre, Rondônia, Alagoas, Distrito Federal, Rio de Janeiro e Paraná. 
Assim, eventualmente as Contas do Governador ou as Contas de Prefeitos acabam sendo aprovadas em face de seu alinhamento partidário, e não necessariamente em face de seu merecimento. Acreditamos, portanto, que mesmo as suas decisões sendo em maioria imparciais e fundamentadas tecnicamente, há algumas delas que não têm qualquer substância, a não ser a retórica que disfarça a sua contaminação por interesses de partidos e grupos privados, e isso é bastante para indicar a necessidade de que o atual sistema de nomeação para as Cortes de Contas seja modificado, adotando-se o sistema de nomeação mediante concurso público de provas e títulos, o mesmo adotado para o provimento dos cargos iniciais das carreiras do Poder Judiciário e do Ministério Público. Dessa forma, poderia haver maior objetividade na seleção de 'julgadores de contas' com qualificação técnica e experiência comprovadas, além de reputação ilibada.

\subsection{O controle exercido pelo Poder Judiciário}

Sem dúvida, o controle exercido pelo Poder Judiciário é um dos mais importantes em nosso sistema constitucional. Somente o judiciário, mediante o devido processo legal, pode determinar a prisão de algum administrador público, a suspensão de seus direitos políticos (em regra) ou a perda de seus bens. Além disso, cabe ao judiciário a última palavra sobre a correta interpretação das leis e da Constituição, e essa competência pressupõe inclusive o poder de anular atos administrativos ilegais ou inconstitucionais, principalmente aqueles que desrespeitam os direitos dos cidadãos, ou que são lesivos ao patrimônio público, ao meio ambiente e a outros bens de interesse difuso ou coletivo. Todavia, o Poder Judiciário, em regra, somente atua por provocação. Não se trata de uma regra que o engessa, ou que esvazia o seu poder, mas antes, de uma regra que o homenageia, pois garante que ele seja exercido com o máximo de imparcialidade, uma vez que a tarefa de acusar e defender são atribuídas a partes diferentes. Em face disso, porém, entendemos mais apropriado analisar o controle judicial da administração quando tratarmos do controle exercido pelo Ministério Público, pelos cidadãos e entidades civis.

Cabe lembrar que o controle do judiciário não pode se imiscuir no exame do mérito administrativo, isto é, na valoração que a administração pública faz em determinados atos administrativos (chamados de discricionários), com relação aos motivos para sua realização e com relação ao seu conteúdo, tendo em vista a 
conveniência e a oportunidade de realização do ato. Felizmente o princípio da motivação, que vincula toda a administração pública brasileira, permite que se faça o controle dos abusos cometidos, pois se os motivos declarados são inexistentes, o ato deixa de ter fundamento e pode ser anulado. Outros limites à discricionariedade do ato administrativo, além da Constituição, das leis e demais normas administrativas, são: i) o princípio da proporcionalidade (que abrange a razoabilidade), segundo o qual o ato: deve guardar adequação entre os motivos, os meios e a finalidade pública do ato, impor a menor restrição possível aos cidadãos, e compensar a restrição com o benefício social alcançado; ii) o princípio da eficiência, que impõe a adoção de padrões técnicos e de racionalização na organização administrativa, na atuação dos agentes e na utilização dos recursos e métodos de trabalho pela administração pública, tendo em vista a otimização da relação custo-benefício nos serviços prestados socialmente.

Acreditamos que quase todos esses limites podem ser controlados pelo Poder Judiciário. No caso do princípio da eficiência, o controle externo deve ser feito preferencialmente pelo Tribunal de Contas competente, quando falhar o controle interno da administração. Somente quando falharem ambos, entendemos que pode o judiciário intervir, não para realizar propriamente o 'controle de eficiência' da administração, mas para determinar aos órgãos competentes que exerçam suas atribuições dentro dos princípios da proporcionalidade, da motivação, da publicidade, da imparcialidade, da moralidade e da legalidade, ao invés de se omitirem. Assim, o único 'controle de eficiência' que pode ser realizado pelo Poder Judiciário é aquele que, por anulação ou correção, recai sobre os atos administrativos que agridem as regras e princípios jurídicos da Administração Pública, sendo em essência um controle de legalidade e/ou de constitucionalidade. As demais ponderações sobre a eficiência administrativa, que não decorrem diretamente do ordenamento jurídico mas antes da observação e aprimoramento contínuos da experiência quotidiana administrativa, devem ser feitas pelos controles interno e externo mencionados.

\subsection{O controle exercido pelo Ministério Público}

A atuação do Ministério Público deve ser ressaltada em relação às demais formas de controle externo, pelo fato de que, além de realizar atos próprios de controle externo da administração 
pública, ele também tem participação importante (seja ela prévia, concomitante ou posterior, conforme veremos) em cada uma das outras formas de controle, e consequentemente na fiscalização da execução de políticas públicas.

A Constituição de 1988, elaborada no bojo do processo de redemocratização brasileiro, conferiu autonomia para a Instituição e independência de atuação para seus membros em graus nunca vistos sob as Constituições brasileiras anteriores. Desde então, o Ministério Público tem exercido inúmeras atribuições em defesa da sociedade, mesmo que para isso tenha que contrariar os interesses de autoridades públicas. Assim, o impedimento (impeachment) do ex-presidente Fernando Collor, decretado pelo Senado Federal em 1992, em decisão histórica, foi possível graças aos dados apurados nas investigações promovidas pelo Ministério Público. Já durante os dois governos do Presidente Fernando Henrique Cardoso (1994-1998 e 1999-2002), a atuação do MP possibilitou o afastamento de senadores e deputados (no âmbito de suas respectivas Casas Legislativas) representantes de oligarquias tradicionais e aparentemente invencíveis, com as quais o Presidente havia se coligado para garantir 'condições de governabilidade', isto é, uma base parlamentar que lhe permitisse aprovar os projetos de lei e de reforma constitucional defendidos pelo governo.

Nessa linha, podemos citar: i) a cassação do mandato do Senador Luís Estevão, tendo em vista notícias de que estaria envolvido no desvio de verbas públicas (169 milhões de reais) para construção da sede do Tribunal Regional do Trabalho de São Paulo. O esquema foi desvendado pelo MP e pela CPI instituída para investigar o Poder Judiciário; ii) a renúncia do Senador Jader Barbalho ao seu mandato, em face das notícias de que havia participado do desvio de verbas públicas (2,5 milhões de reais) da antiga Superintendência para Desenvolvimento da Amazônia (Sudam), na época em que havia sido governador do Estado do Pará; iii) a renúncia do Senador Antônio Carlos Magalhães ao seu mandato, em face das notícias de que o Senador havia violado o sigilo da votação secreta que decidiu pela cassação do Senador Luís Estevão; iv) a cassação do mandato do Deputado Hildebrando Aciolly, após ser apurado pelo MP e pela CPI criada para investigar o narcotráfico que o parlamentar estava envolvido com o tráfico ilícito de entorpecentes e com o assassinato cruel de pessoas, em seu Estado de origem, o Acre. Esses são apenas alguns dos casos que explicam por que atualmente o Ministério Público trata-se do ins- 
trumento de maior credibilidade a respeito do controle do poder público.

O Ministério Público não pode ser enquadrado em nenhum dos três poderes convencionais. A autonomia institucional do Ministério Público está expressa na Constituição Federal (art. 127 $\int \mathbb{S} 2^{\circ}, 3^{\circ}$, e art. 168): é funcional, administrativa e financeira. ${ }^{9} \mathrm{O}$ Ministério Público (que existe na União e nos Estados) é órgão constitucional permanente, essencial à função jurisdicional do Estado, incumbindo-lhe a defesa da ordem jurídica (pois que ele é o fiscal da execução das leis e da obediência à Constituição) do regime democrático, dos interesses sociais e dos interesses indisponíveis, referentes, por exemplo, aos direitos assegurados na Constituição, sejam eles individuais e/ou sociais, como o direito à vida, à liberdade, à educação e à saúde, sejam eles difusos, como os relativos ao patrimônio público, ao meio ambiente e ao patrimônio cultural.

Além disso, pode promover também a defesa de interesses disponíveis, como os direitos de categorias profissionais e de consumidores, quando houver extraordinária abrangência ou dispersão dos lesados, ou quando for necessária para assegurar o funcionamento de todo um sistema jurídico, econômico ou social (Mazzilli, 2001: 152). Cabe ao MP a tarefa de zelar pelo efetivo respeito dos Poderes Públicos e dos serviços de relevância pública aos direitos assegurados na Constituição, promovendo as medidas necessárias à sua garantia (Constitução Federal, 1988: art. 129, II,). O MP compõe-se de promotores e procuradores aprovados em concursos públicos de provas e títulos (os quais são acompanhados pela Ordem dos Advogados do Brasil), o que nos faz supor que tais agentes são profissionais altamente qualificados.

Os membros do MP detêm independência funcional para agir sem qualquer tipo de influência externa. Isto é, eles só se sujeitam ao controle de órgãos superiores e diretivos da instituição, e mesmo assim somente na sua conduta administrativa ao longo da carreira (como nos casos de solução de um conflito de atribuições, imposição de medidas disciplinares, revisão de uma promoção de arquivamento de inquérito civil ou de inquérito policial), ou nos seus atos pessoais que afrontem a probidade e os demais deveres legais e constitucionais aos quais estão vinculados. De resto, os membros do Ministério Público atuam com total liberdade fun-

${ }^{9}$ A autonomia institucional do MP é tão importante que a Constituição Federal, no art. 85, II, considera crime de responsabilidade o ato do Presidente da República que atente contra o exercício das funções do MP. 
cional, e não estão sujeitos a qualquer subordinação hierárquica ou supervisão de qualquer dos órgãos estatais. Essa independência funcional no exercício das funções do MP, por sua vez, é assegurada por um sistema de garantias, vedações e prerrogativas para seus membros, que é similar ao estabelecido para garantir a independência funcional dos juízes (Mazzilli, 2001: 156-157; 189190). ${ }^{10}$

Para a defesa dos interesses e direitos que lhe cabe promover, o Ministério Público pode tomar inúmeras providências, e que importam em controle externo das entidades da administração pública direta, indireta e de outros entes privados que prestam serviços públicos ou de relevância pública. Sempre que o membro do MP tiver notícia de qualquer ilegalidade ou abuso praticado por tais entidades, ou até pelos cidadãos, mas em prejuízo dos interesses sociais, deve a princípio instaurar procedimento administrativo para apurar o fato, tendo poderes de fazer requisições, expedir notificações e intimações, com vistas a instruir o feito. A falta injustificada e o retardamento indevido do cumprimento das requisições do MP implicarão a responsabilidade de quem lhe der causa. ${ }^{11}$

Na tentativa de promover a correção da ilegalidade sem a provocação do Poder Judiciário, o MP poderá expedir recomendações, visando à cessação das ilegalidades e à correção das condutas, fixando prazo razoável para a adoção das providências cabíveis. Além disso, o Ministério Público poderá promover o ajustamento

${ }^{10}$ São garantias (Constitução Federal, 1988: art. $128 \$ 5^{\circ}$ ): i) vitaliciedade, após dois anos de exercício, não podendo perder o cargo senão por sentença judicial transitada em julgado; ii) inamovibilidade no cargo e no exercício de suas funções, salvo por motivo de interesse público, mediante decisão do órgão colegiado competente do MP, por voto de dois terços de seus membros, assegurada ampla defesa; iii) irredutibilidade de subsídio (remuneração). São vedações (Constitução Federal, 1988: art. 128 \$ $5^{\circ}$, II): i) receber honorários, percentagens ou custas processuais; ii) exercer a advocacia; iii) participar de sociedade comercial, na forma da lei; iv) exercer qualquer outra função pública, salvo uma de magistério; v) exercer atividade político-partidária, salvo exceções previstas na lei. Cabe ainda mencionar uma prerrogativa dos membros do MP: a de não ser julgado pelo mesmo juízo dos cidadãos comuns. Sempre serão os membros do MP julgados por Tribunais ou Órgãos colegiados diferentes dos juízos com quem tais membros atuam quotidianamente.

${ }^{11}$ Constitução Federal, 1988: art. $8^{\circ}, \mathbb{S} 3^{\circ}$, LC 75/93. Pode o MP realizar os seguintes atos: notificar testemunhas e requisitar sua condução coercitiva, no caso de ausência injustificada; requisitar informações, exames, perícias, serviços temporários e documentos de autoridades da administração pública direta ou indireta; requisitar informações e documentos a entidades privadas; realizar inspeções e diligências investigatórias; ter livre acesso a qualquer local público ou privado, respeitadas as normas da inviolabilidade do domicílio; ter acesso incondicional a qualquer banco de dados de caráter público ou relativo a serviço de relevância pública; requisitar o auxílio de força policial (Lei 8625/93: art. $8^{\circ}$, I a IX, LC 75/93, art. 80). 
da conduta de tais entidades à lei e à Constituição, mediante a assinatura de um termo/acordo com combinações específicas, o qual tem eficácia de título executivo extrajudicial (Lei 7347/85: art. $5^{\circ} \sqrt{ } 6^{\circ}$ ). Cabe apenas lembrar que a assinatura do acordo não impede a promoção de ação judicial visando à reparação dos danos causados (caso esta não seja prevista pelo próprio termo), uma vez que o termo visa a regular a conduta a partir do momento de sua assinatura.

O Ministério Público tem atuação importante junto às demais formas de controle externo da administração pública. Assim, por exemplo, quando não consegue fazer com que entidades públicas, privadas ou até mesmo pessoas deixem de cometer ilegalidades, deve promover junto ao Poder Judiciário ações civis públicas para a defesa de interesses difusos, coletivos ou mesmo de interesses individuais homogêneos (como no caso de vários consumidores lesados pelo fornecedor de algum produto).

Além disso, compete constitucionalmente ao Ministério Público promover privativamente a ação penal pública junto ao Poder Judiciário, necessária para se apurar a prática da maioria absoluta dos crimes, tendo em vista que em nosso direito poucos crimes são julgados mediante iniciativa da pessoa lesada ou de seu representante legal. Assim, em regra, se durante o controle externo da administração (pelo Parlamento, pelos Tribunais de Contas, pelo MP e pelos cidadãos e entidades civis) apura-se a prática de algum crime, os supostos responsáveis serão em regra processados na esfera penal pelo Ministério Público, junto ao Poder Judiciário. Para melhor desempenhar suas atribuições de órgão de acusação, $\mathrm{O}$ MP tem poderes de requisitar à autoridade policial a instauração de inquérito policial, para coleta de provas e apuração de responsabilidades, podendo também requisitar diligências investigatórias específicas, acompanhar a produção de provas ou coletar provas independentemente da atuação policial (Lei 8625/93: art. $7^{\circ}$, II, LC 75/93; art. 80).

Dentre os crimes a serem investigados, encontram-se os praticados contra a administração pública, como o peculato (apropriação ou desvio de bens públicos) e a aplicação irregular de verbas públicas, os recentes crimes contra as finanças públicas, como por exemplo os de realizar operações de crédito ou ordenar despesas sem autorização legislativa, ou acima dos limites fixados em lei. Assim, contribui o MP com o trabalho dos Tribunais de Contas na fiscalização da gestão responsável dos recursos públi- 
cos por parte dos administradores públicos, ainda que sua participação fique mais adstrita à esfera criminal neste caso.

Cabe ainda ao MP promover judicialmente a ação de improbidade administrativa (que não se confunde com a ação penal), visando à decretação da perda do cargo da autoridade pública que tenha causado dano ao erário (cujo ressarcimento integral também deverá ser promovido na ação), enriquecendo-se ilicitamente ou não, ou que tenha descumprido os princípios da administração pública. ${ }^{12}$

O Ministério Público deverá promover ações junto à justiça eleitoral, visando à impugnação do registro de candidatos a cargo eletivo que: i) venham a concorrer no período de cinco anos a contar da decisão irrecorrível que rejeitou as suas contas relativas ao exercício de cargos ou funções públicas. Essa decisão em regra cabe aos Tribunais de Contas, e no caso das contas do Chefe do Executivo, cabe ao Poder Legislativo; ii) tenham sido condenados criminalmente, por sentença transitada em julgado, pela prática de crimes contra a economia popular, a fé pública, a administração pública, o patrimônio público e o mercado financeiro; crime de tráfico de entorpecentes e crimes eleitorais; iii) tenham cometido abuso de poder político ou de poder econômico, durante campanha eleitoral ou com finalidades eleitorais, conforme decidido por sentença transitado em julgado proferida pela justiça eleitoral (LC 64/90: art. 10, I, “d” e "h").

O Ministério Público atua ainda promovendo ações de inconstitucionalidade contra atos normativos do Executivo e leis que contrariam a Constituição; emitindo pareceres em processos de habeas corpus, ${ }^{13}$ de habeas data, ${ }^{14}$ de mandado de segurança, ${ }^{15} \mathrm{e}$

${ }^{12}$ Cf. a Lei 8429/92, outras medidas a serem decretadas na sentença da ação de improbidade são a perda dos bens ou valores acrescidos ilicitamente ao patrimônio, a suspensão dos direitos políticos de 3 até 10 anos, o pagamento de multa civil, a proibição de contratar com o poder público e de receber incentivos ou benefícios fiscais ou creditícios, por prazos de 3,5 e 10 anos.

${ }^{13}$ Conceder-se-á habeas corpus sempre que alguém sofrer ou se achar ameaçado de sofrer violência ou coação em sua liberdade de locomoção, por ilegalidade ou abuso de poder (Constitução Federal, 1988: art. $5^{\circ}$, LXVIII).

${ }^{14}$ Conceder-se-á habeas data: i) para o conhecimento de informações sobre a pessoa do impetrante, constantes de registros de dados de entidades governamentais ou de caráter público; ii) para a retificação de dados, quando não se opte por processo sigiloso, judicial ou administrativo (Constitução Federal, 1988: art. 5, LXXII).

${ }^{15}$ Conceder-se-á mandado de segurança para proteger direito líquido e certo, não amparado por habeas corpus ou habeas data, quando o responsável pela ilegalidade ou abuso de poder for autoridade pública ou agente de pessoa jurídica no exercício de atribuições do Poder Público (Constitução Federal, 1988: art. 5, LXIX). 
em processos onde há interesse de crianças, adolescentes e outros incapazes.

Considerando-se o controle externo exercido pelo Poder Legislativo sobre a Administração Pública, especificamente no que tange às Comissões Parlamentares de Inquérito (CPI), não cabe ao MP participar ou intervir em seus trabalhos, mas considerando que a tais comissões cabe apenas apurar fatos e não aplicar punições, caberá ao órgão ministerial dar andamento às investigações feitas no âmbito de tais comissões, uma vez que estas lhe devem remeter suas conclusões para a promoção das medidas judiciais cabíveis, visando à responsabilidade civil e criminal dos envolvidos nos casos que tenham sido investigados (Constitução Federal, 1988: art. $\left.58, \mathbb{S} 3^{\circ}\right)$. Em outras palavras, competirá ao MP promover junto ao Poder Judiciário as ações para ressarcimento dos danos causados ao erário público e para condenação penal dos responsáveis investigados pelas CPI. Lembre-se ainda que nada impede que as investigações sejam realizadas ao mesmo tempo por tais Comissões e pelo MP, de forma independente mas integrada.

Com relação ao controle exercido pelos cidadãos e entidades da sociedade civil, sempre que os órgãos públicos se negam a prestar informações aos cidadãos, acerca de questões de seu interesse ou de interesse social, o MP poderá intervir para corrigir o abuso. Caso um cidadão promova uma ação popular, visando à anulação de ato administrativo lesivo ao patrimônio público, ou no caso de uma entidade pública ou de uma associação civil promover uma ação civil pública, para a defesa de interesses difusos, coletivos ou individuais homogêneos, o MP deverá acompanhar o andamento do processo, zelar pela sua boa condução, requerendo as medidas e as provas que entender cabíveis, e se o cidadão ou a entidade desistir da ação, o MP deverá assumir a promoção ativa do proces-

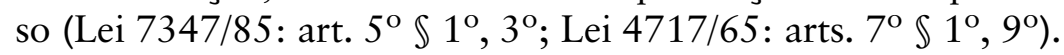

Uma outra iniciativa importante que pode ser promovida pelo Ministério Público no tocante à fiscalização popular sobre os poderes públicos é a realização de audiências públicas (Lei 8625/93: art. 27, par. único, IV), por meio das quais são discutidas questões envolvendo os interesses da comunidade de uma determinada região. De tais audiências participam os cidadãos e entidades civis interessados; os membros do poder público; profissionais qualificados nos assuntos a serem discutidos; membros de empresas e outras entidades privadas com interesse no desenvolvimento de determinados projetos. O MP pode assumir importante papel na promoção de tais audiências, como um mediador, e ao mesmo 
tempo um fiscalizador do cumprimento das leis. Acreditamos que tais audiências podem ser promovidas também sobre questões referentes ao desenvolvimento urbano, com relação ao plano diretor e aos orçamentos municipais. ${ }^{16}$ Ressalte-se que as audiências públicas podem ser também promovidas pelo Poder Público ou pelas próprias comunidades interessadas, não sendo necessária sempre a participação do MP. Como todavia cabe a ele ser o fiscal da lei, a sua presença possibilita um maior cumprimento dela e da Constituição.

\subsubsection{Críticas ao sistema de nomeação do Chefe do Ministério Público}

Os membros do MP têm realmente se destacado na defesa dos interesses maiores da sociedade. Todavia, uma crítica deve ser feita ao sistema de nomeação do Chefe da Instituição, que depende de indicação do Chefe do Poder Executivo. $\mathrm{Na}$ verdade, trata-se de um resquício do sistema constitucional anterior, em que o MP acumulava as funções próprias de Ministério Público (como as de defensor da sociedade e fiscal da lei) com as funções de Advocacia de Estado. Assim, era compreensível que naquele regime o Poder Executivo precisasse de alguém de sua confiança para exercer o cargo. Isso todavia gerava uma atuação contraditória no seio da Instituição, pois em caso de a sociedade ser vítima de abusos praticados pela administração pública, um membro do MP deveria processar a autoridade responsável, enquanto outro deveria defender o ato praticado.

A Constituição Federal de 1988 avançou ao ter separado as funções de defesa da sociedade e da lei das funções de advocacia de Estado, atribuindo-as a Instituições distintas, mas infelizmente manteve a nomeação do Chefe do Ministério Público vinculada à escolha do Chefe do Poder Executivo. Críticas podem ser feitas ao atual sistema, afinal de contas, em caso de o Chefe do Poder Executivo cometer algum crime, quem promoverá a ação penal junto ao Poder Judiciário será justamente o Chefe do Ministério

${ }^{16}$ Assim, o art. 40 da Lei 10257/2001 (Estatuto das Cidades), prevê que a elaboração e a fiscalização da implantação do plano diretor, instrumento básico da política de desenvolvimento urbano, devem ter a participação da população assegurada, por meio de debates e audiências públicas, onde sejam parte as associações representativas dos vários segmentos da sociedade. O art. 44 , por sua vez, prevê a participação da população, por meio de consultas, debates e audiências públicas, como condição obrigatória para a aprovação do plano plurianual, da lei de diretrizes orçamentárias e do orçamento anual, no âmbito dos municípios. 
Público. Em outras palavras: o 'fiscalizado' escolhe seu 'fiscalizador', o que realmente parece absurdo. Mas o atual sistema não é tão ruim assim, pois nele o Chefe do Ministério Público é nomeado para uma investidura por tempo certo (dois anos), e não pode mais ser afastado do cargo por iniciativa unilateral do Chefe do Poder Executivo, conforme dispunham as Constituições anteriores (Sauwen Filho, 1999: 121-160). Para tanto, sempre necessitará de autorização da maioria absoluta dos membros do Legislativo (Constitução Federal, 1988: art. $128 \mathbb{S} 2^{\circ}, 4^{\circ}$,).

Foi justamente o sistema atual de nomeação e destituição não tão vinculado à vontade do Executivo que permitiu que o primeiro Procurador-Geral da República sob o novo sistema propusesse a única ação penal (por crime comum) de que se tem notícia contra um Presidente da República em pleno exercício do cargo. Apesar de o ex-Presidente Fernando Collor de Mello ter sido absolvido no processo movido perante o Supremo Tribunal Federal, os fatos apurados pelo Ministério Público ensejaram a decretação do impeachment do Presidente (perda do cargo por crime de responsabilidade) pelo Senado Federal, conforme citado anteriormente.

Todavia, não se pode negar que a escolha do Chefe do MP pelo Chefe do Poder Executivo possibilita que ainda haja interferência política e governamental na Chefia da Instituição, pois caberá à pessoa nomeada aceitar ou não tais interferências (Mazzilli, 2001: 119). Essas interferências são ilegais, mas podem ser identificadas quando o Chefe do MP deixa de promover ações que contrariam o governo ou seus aliados, tendo em vista sua possível recondução ao cargo no futuro, ou até mesmo outras vantagens inomináveis. ${ }^{17}$

${ }^{17}$ Em 06/06/2001, semanas antes de o Senado reconduzi-lo pela terceira vez ao cargo de Procurador-Geral da República, a Revista Veja (2001: 125-126), noticiou que Geraldo Brindeiro tinha 4,514 processos parados na gaveta e ainda queria um quarto mandato, já estando em campanha junto a parlamentares do PMDB e do PFL. Dos 4,514 processos, a Revista ressaltou os inquéritos, por tratarem de investigações criminais contra autoridades estaduais (como governadores) ou federais. É um tipo de processo que só anda se tiver um parecer do Procurador-Geral da República. Segundo a reportagem, desde que assumira o cargo, em junho de 1995, Brindeiro já recebera 626 inquéritos. Destes, $242(38.6 \%)$ encontravam-se “na gaveta” (isto é, parados, a espera de parecer); 217 (34.7\%) haviam sido arquivados; 60 (9.6\%) haviam resultado em denúncia; 88 (14.1\%) haviam sido devolvidos à Justiça; 19 (3.0\%) encontravam-se em investigação. Dos 242 inquéritos 'na gaveta', 194 eram sobre Deputados Federais, 33 sobre Senadores, 11 sobre Ministros e ex-ministros e 4 sobre o Presidente. No ano em que este artigo foi escrito (2002), o então Procurador-Geral da República, Geraldo Brindeiro, encontrava-se em seu quarto 'mandato' consecutivo (foi reconduzido ao cargo três vezes). Em 06/06/2001, a Revista Veja (2001: 125-126), noticiou que o ProcuradorGeral da República, em seis anos, fez somente seis contestações a medidas do Governo Federal. O Procurador-Geral anterior, Aristides Junqueira, em seis anos de 'mandato', 
Para que realmente fosse assegurada a autonomia funcional da Instituição ministerial, seria necessário que se retirasse qualquer interferência do Poder Executivo sobre a nomeação do Chefe do MP. Além disso, a possibilidade de interferência política de grupos de pressão que atuam no Congresso, bem como a possibilidade de distorção dos processos eleitorais populares (como manipulação dos meios de comunicação), desaconselham que tal nomeação fique a cargo do Poder Legislativo ou a cargo da população. Assim, entendemos que a nomeação do Chefe do MP deve caber exclusivamente aos membros da Instituição, por eleição direta, posto que têm não só a formação técnica, mas também o conhecimento do trabalho desenvolvido por seus colegas, ambos necessários para se escolher um Chefe capaz, honesto e que seja atuante e comprometido com a missão da Instituição. ${ }^{18}$

Embora a atuação do Chefe do Ministério Público (seja na esfera federal, seja na esfera dos Estados e do Distrito Federal) nem sempre tenha sido a mais correta, isso todavia não retira o mérito das ações promovidas pelos vários membros da Instituição, que não tendo qualquer vinculação com os poderes constituídos, têm atuado em regra de forma capaz e independente, contribuindo de inúmeras formas para o aperfeiçoamento das formas de controle exercidas sobre a administração pública.

\subsection{O controle social da administração pública}

Nosso sistema jurídico prevê inúmeras formas de controle da administração pelo Poder Judiciário, como resultado da participação da população, como no caso das ações de habeas corpus, habeas data, e mandado de segurança (já mencionadas). Merecem destaque, todavia: i) a ação popular, que pode ser

nos governos de Fernando Collor e Itamar Franco, apresentou 56 contestações. Não é possível que essa diferença se deva apenas ao fato de o atual Governo Federal cometer menos deslizes do que os governos anteriores.

${ }^{18}$ Sauwen Filho (1999: 172-174), essa foi a fórmula vencedora de pesquisa realizada em 1985 entre os membros do MP em todo o país, por parte da Confederação Nacional do Ministério Público (Conamp). Dos 977 membros que responderam a consulta, 606 optaram pela eleição direta para Procurador-Geral (275 por toda a classe indistintamente, 199 somente por membros estáveis, 132 pelo Colégio de Procuradores), 221 optaram pelo sistema que combina elaboração de lista tríplice pela Instituição, para escolha de um nome pelo Chefe do Executivo (92 entenderam que a lista tríplice deveria ser elaborada pelo Colégio de Procuradores, 60 por toda a classe indistintamente, e 69 somente por membros estáveis) e apenas 15 optaram pelo sistema de livre nomeação pelo Chefe do Executivo; os restantes abstiveram-se. Ressalte-se ainda que 810 (contra 67) entenderam ser desnecessária a ratificação do nome escolhido pelo Poder Legislativo. 
promovida por qualquer cidadão, visando a anular ato lesivo ao patrimônio público, à moralidade administrativa, ao meio ambiente e ao patrimônio histórico e cultural, ficando o autor, salvo comprovada má-fé, isento de custas judiciais e do ônus da sucumbência (Constitução Federal, 1988: art. $5^{\circ}$, LXXIII); ii) a ação civil pública, que pode ser promovida por qualquer associação civil, visando à proteção ao meio ambiente, ao consumidor, à ordem econômica, à livre concorrência, ou ao patrimônio artístico, estético, histórico, turístico e paisagístico, desde que a associação esteja constituída há pelo menos um ano (requisito que pode ser dispensado em casos de grande dano à sociedade ou de relevância do bem jurídico a ser protegido) e tenha o objetivo da ação inserido em suas finalidades institucionais (Lei 7347/85: art. $5^{\circ}$, caput e $\$ 4$ ).

Pode ainda a sociedade participar do Controle que é exercido pelos Tribunais de Contas sobre os administradores públicos, uma vez que é direito de qualquer cidadão, partido político, associação ou sindicato denunciar irregularidades ou ilegalidades perante tais Cortes (Constitução Federal, 1988: art. $74 \mathbb{S} 2^{\circ} \mathrm{c} / \mathrm{c}$ art. 75 ). Da mesma forma, nada impede que os cidadãos e entidades civis interessadas levem ao conhecimento do Poder Legislativo e/ou do MP irregularidades/ilegalidades que estejam sendo praticadas por administradores públicos, com vistas a provocar a atuação fiscalizatória de tais Instituições.

Destacaremos, todavia, as formas de controle que são exercidas diretamente pelos cidadãos e entidades civis sobre a administração pública, ou porque independem da atuação de outros órgãos/instituições estatais (Poder Legislativo, Tribunais de Contas, Poder Judiciário e Ministério Público), ou porque, deles dependendo, envolvem processos decisórios a cargo da população.

Como exemplos de controle popular existentes em nosso ordenamento jurídico, podemos citar o direito de requerer junto aos órgãos públicos informações de interesse particular ou geral (Constitução Federal, 1988: art. $5^{\circ}$, XXXIII); o direito de petição aos Poderes Públicos em defesa de direito ou contra ilegalidade ou abuso de poder, bem como a obtenção de certidões em repartições públicas, para defesa de direitos e esclarecimento de situações de interesse pessoal, independentemente do pagamento de taxas (Constitução Federal, 1988: art. 5, xxxIv).

Tendo em vista o mencionado processo, constatado na Federação Brasileira, de descentralização na execução das políticas públicas referentes aos direitos da cidadania, o qual resulta no aumento de responsabilidades das esferas locais de governo, é 
necessário dar ênfase para a participação da população local em atividades de planejamento, execução e fiscalização de tais políticas, justamente nas regiões onde elas devem ser implementadas.

A necessidade de participação da população no planejamento das ações do município foi reconhecida expressamente pela Constituição Federal, quando reconheceu às associações representativas da sociedade o direito de cooperarem com o planejamento municipal, sendo tal participação preceito fundamental a ser adotado em todas as Leis Orgânicas Municipais (Constitução Federal, 1988: art. 29). Além disso a gestão democrática das esferas políticas locais foi desenvolvida pelo Estatuto da Cidade, lei recente que estabelece diretrizes para a política de desenvolvimento urbano, mediante a previsão dos seguintes instrumentos: i) órgãos colegiados de política urbana, nos níveis nacional, estadual e municipal; ii) debates, audiências e consultas públicas; iii) conferências sobre assuntos de interesse urbano, nos níveis nacional, estadual e municipal; iv) iniciativa popular de projeto de lei e de planos, programas e projetos de desenvolvimento urbano; v) realização de debates, audiências e consultas públicas sobre as propostas do plano plurianual, da lei de diretrizes orçamentárias e do orçamento anual, como condição obrigatória para sua aprovação pela Câmara Municipal; vi) obrigatória e significativa participação da população e de associações representativas dos vários segmentos da comunidade nos organismos gestores das regiões metropolitanas e aglomerações urbanas, de modo a garantir o controle direto de suas atividades e o pleno exercício da cidadania; vii) participação da população e de associações representativas dos vários segmentos da comunidade na formulação, execução e acompanhamento de planos, programas e projetos de desenvolvimento urbano (Lei 10.257/2001: art. $2^{\circ}$, II, arts. 43, 44 e 45).

Dentre tais instrumentos, merece destaque o orçamento participativo, como uma nova forma de planejar e executar as políticas públicas, combatendo-se os vícios do patrimonialismo e do clientelismo. A esse respeito deve ser citada a experiência da cidade de Porto Alegre, que tornou-se referência mundial, por ter possibilitado um gestão eficaz e democrática dos recursos urbanos, e foi escolhida pelas Nações Unidas com uma das quarenta inovações urbanas em todo o mundo, para ser apresentada na Conferência Mundial das Nações Unidas sobre Assentamentos Humanos (Habitat II, que ocorreu em Istambul, em junho de 1996). Não é sem motivo, portanto, que o Banco Mundial desde 1993 tem divulgado e promovido o modelo de gestão urbana do muni- 
cípio, inclusive concedendo-lhe empréstimos. A revista Exame, por sua vez, em várias ocasiões já elegeu Porto Alegre como a cidade brasileira com melhor qualidade de vida, com base nos seguintes indicadores: alfabetização, matrículas no ensino básico e secundário, qualidade do ensino superior e da pós-graduação, consumo per capita, emprego, mortalidade infantil, esperança de vida, número de leitos por hospital, habitação, esgotos, aeroportos, auto-estradas, taxa de criminalidade, restaurantes e clima (Santos, 2002: 460-461).

O orçamento participativo de Porto Alegre baseia-se em três princípios básicos: i) todos os cidadãos têm o direito de participar, sendo que as organizações comunitárias não detém, a este respeito, pelo menos formalmente, status ou prerrogativas especiais; ii) a participação é dirigida por uma combinação de regras de democracia direta e de democracia representativa, e realiza-se através de instituições de funcionamento regular cujo regimento interno é determinado pelos participantes; iii) os recursos de investimento são distribuídos de acordo com um método objetivo baseado em uma combinação de 'critérios gerais' -critérios substantivos, estabelecidos pelas instituições participativas com vista a definir prioridades- e de "critérios técnicos" -critérios de viabilidade técnica ou econômica, definidos pelo Executivo, e normas jurídicas federais, estaduais ou da própria cidade, cuja implementação cabe ao Executivo (Santos, 2002: 467).

O orçamento participativo é essencial para uma melhor distribuição dos recursos públicos pelas várias regiões da cidade, principalmente no que tange à realização de obras e investimentos em infra-estrutura urbana, possibilitando uma execução mais justa das políticas públicas de saneamento básico, de habitação e de desenvolvimento urbano, bem como das de educação e de saúde, quando envolvem, por exemplo, a construção de escolas, hospitais e postos de saúde.

Uma importante iniciativa que tem possibilitado o controle popular sobre a execução de políticas públicas, no que tange aos direitos de saúde e de educação, tem sido a instituição de conselhos com participação da sociedade civil, para fiscalizar a aplicação dos recursos públicos. ${ }^{19}$

\footnotetext{
${ }^{19}$ Podem ser citados ainda os conselhos que devem existir nos vários níveis de governo, nas áreas de proteção da infância e adolescência, combate ao narcotráfico, proteção ao idoso, proteção ao meio ambiente. Tais conselhos têm a atribuição de traçar a política para determinada área de atuação estatal, e ao menos no caso dos Conselhos Tutelares de Proteção à Infância e à Adolescência, e no caso dos Conselhos Anti-Drogas,
} 
Assim, em todos os níveis da federação brasileira, devem existir Conselhos de Saúde, que são órgãos colegiados, de caráter permanente e deliberativo, compostos por representantes do governo, prestadores de serviço, profissionais de saúde e usuários, e que atuam na formulação de estratégias e no controle da execução da política de saúde na instância correspondente, inclusive nos aspectos econômicos e financeiros, sendo suas decisões homologadas pelo chefe do poder legalmente constituído em cada esfera de governo. A lei que institui os Conselhos determina que a metade de seus membros seja constituída por 'usuários do sistema', sendo a outra metade integrada pelos demais segmentos mencionados. Assim, a sociedade tem participação significativa em tais órgãos. E uma outra novidade interessante trazida pela lei foi a exigência da instituição de tais Conselhos como uma das condições para que seja realizado o repasse de recursos federais da saúde para os Municípios, Estados e Distrito Federal (Lei 8142/

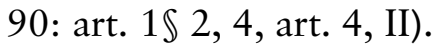

No que tange à política de educação, a Lei de Diretrizes e Bases da Educação Nacional estabelece que cada sistema de ensino (federal, estadual e municipal) deverá estabelecer a gestão democrática do ensino público na educação básica, onde haja participação dos profissionais da educação na elaboração do projeto pedagógico da escola, e participação das comunidades escolar e local em conselhos escolares ou equivalentes. Além disso, a Lei determina que os sistemas de ensino assegurarão às unidades escolares públicas de educação básica que os integram progressivos graus de autonomia pedagógica e administrativa e de gestão financeira, observadas as normas gerais de direito financeiro público. Isso significa um importante avanço na gestão descentralizada dos recursos na política de educação, pois garante que cada uni-

também há a competência para fiscalizar a execução da política pública. Merece ser mencionado ainda o caso da gestão dos recursos hídricos, que segundo a Lei 9433/97 deve ser descentralizada e contar com a participação do Poder Público, dos usuários e das comunidades. Os órgãos para formulação da política pública de uso dos recursos hídricos são o Conselho Nacional, os Conselhos dos Estados e do Distrito Federal e os Comitês de Bacia Hidrográfica (que reúnem as autoridades da União, do municípios e eventualmente dos Estados que partilham a mesma bacia hidrográfica, além dos usuários e de representantes da sociedade civil organizada). As Agências de Água, de âmbito estadual (além da Agência Nacional de Águas, de âmbito federal), cuidam da fiscalização da política nacional e da arrecadação das receitas vindas da cobrança do uso das águas, sendo que será a partir dos planos de bacia hidrográfica (de âmbito local/regional) que deverão ser formulados os planos estaduais e o plano nacional. Ressalte-se ainda que a administração das águas ficará a cargo das Agências e dos Comitês de Bacia Hidrográfica. 
dade escolar terá autonomia para gerir seus recursos, e que isso será feito sob a fiscalização das comunidades escolar e local.

Como exemplo desse avanço em termos de gestão, deve ser citado o Programa Dinheiro Direto na Escola (PDDE), criado em 1995 pelo Ministério da Educação. O Fundo Nacional de Desenvolvimento da Educação (FNDE) repassa recursos federais diretamente às unidades escolares estaduais e municipais do ensino fundamental, com mais de 20 alunos matriculados. Esse repasse direto de recursos traz autonomia e agilidade às escolas, eliminando a burocracia, garantindo o funcionamento de suas decisões e favorecendo o exercício da cidadania, uma vez que mobiliza a comunidade e promove o seu envolvimento nas atividades escolares. ${ }^{20}$

Dentre desse espírito de autonomia, uma das condições para o repasse dos recursos é a criação de organizações representativas da comunidade, chamadas de "Unidades Executoras" (UEX), que são associações civis sem fins lucrativos, responsáveis pela gestão planejada dos recursos públicos recebidos, de acordo com as prioridades e o projeto pedagógico da respectiva unidade de ensino. ${ }^{21}$ Os recursos são depositados diretamente na conta corrente da UEx, que decide onde eles serão aplicados e, posteriormente, presta contas da gestão dos recursos à Secretaria de Educação do Município ou do Estado respectivo, que por sua vez faz a prestação de contas ao FNDE e ao Tribunal de Contas correspondente.

O modelo de gestão descentralizada e democrática tem mostrado resultados positivos, de forma que Estados e municípios têm progressivamente implantado o repasse direto de recursos para as unidades escolares estaduais e municipais, os quais são então geridos pelas UEx existentes. É o que se observa, por exemplo, no Estado do Rio de Janeiro.

Podemos citar ainda o controle social exercido sobre alguns programas específicos promovidos no País, para efetivação do direito à educação: i) o Programa Nacional de Renda Mínima Bolsa Escola; ii) o Programa Nacional de Alimentação Escolar;

${ }^{20}$ Os recursos do PDDE podem ser utilizados na aquisição de material permanente; manutenção, conservação e pequenos reparos da unidade escolar; aquisição de material de consumo necessário ao funcionamento da escola; capacitação e aperfeiçoamento de profissionais da educação; avaliação de aprendizagem; implementação de projeto pedagógico; e desenvolvimento de atividades educacionais.

${ }^{21}$ No caso de unidades escolares com menos de 100 e mais de 20 alunos matriculados, se não houver Unidade Executora instituída, o repasse será indireto, sendo intermediado pela Prefeitura ou pela Secretaria de Educação do Estado ou do Distrito Federal. Para as escolas com 100 alunos ou mais, todavia, a criação das uEx é obrigatória para a participação no PDDE. 
iii) o Programa do Fundo Nacional de Manutenção e Desenvolvimento do Ensino Fundamental e Valorização do Magistério.

O Programa Nacional de Renda Mínima Bolsa Escola, criado pelo Governo Federal, em meados de 2002 já tinha a adesão de 5,536 dos então 5,561 municípios existentes no país, tendo como objetivo evitar a evasão escolar no ensino fundamental, proporcionando uma "bolsa" mensal de R 15.00 (até o limite de R\$ 45.00 por família) para o estudante que tiver $85 \%$ de freqüência mínima às aulas. Uma das condições para que o município participe do programa é a criação do "Conselho de Controle Social", que deve ter no mínimo a metade de seus membros não vinculada à administração municipal, isto é, composta por membros da sociedade civil. O conselho tem a função de acompanhar e avaliar a execução do programa, aprovar a relação de famílias cadastradas pelo Poder Executivo Municipal e estimular a participação comunitária em tal controle. Lembre-se que o programa visa a evitar a evasão escolar, logo pressupõe a atuação integrada de professores, diretores de escolas e pais de alunos, de forma a manter os alunos na escola.

O Programa Nacional de Alimentação Escolar repassa recursos federais para alimentar cerca de 37 milhões de estudantes do ensino fundamental por dia, durante os 200 dias do ano letivo (calendário escolar). Desde sua criação, em 1954, até 1993, o Programa era gerenciado centralizadamente no Governo Federal. A partir de 1994, houve a descentralização da execução do Programa com a celebração de convênios com os Estados, DF e municípios. Estes atualmente recebem os recursos para a execução do programa diretamente do Fundo Nacional de Desenvolvimento da Educação, desde que instituam um Conselho de Alimentação Escolar, órgão colegiado composto por representantes dos Poderes Executivo e Legislativo, dos professores, dos pais de alunos e de outros segmentos da sociedade local, com competência de fiscalizar a aplicação dos recursos. O CAE analisa a prestação de contas feita pela entidade executora, emitindo pareceres a respeito, e anualmente envia um relatório acerca da execução do programa para o FNDE. ${ }^{22}$

${ }^{22}$ Cf. site do Fundo Nacional de Desenvolvimento da Educação, <http:// www.fnde.gov.br>, agosto de 2002, o Programa Nacional de Alimentação Escolar fornece recursos suplementares para garantir que $15 \%$ das necessidades nutricionais diárias das crianças matriculadas na pré-escola e no ensino fundamental sejam atendidos. A complementação alimentar fica a cargo dos Estados, DF e municípios beneficiados. 
Por sua vez, o Programa de Desenvolvimento do Ensino Fundamental e Valorização do Magistério é financiado por um Fundo (FUNDEF), instituído no âmbito de cada Estado (e do Distrito Federal), e constituído por recursos pertencentes aos Estados, Distrito Federal e municípios (podendo haver complementação por parte da União Federal), que são responsáveis por sua execução. A Lei 9424/96 determina que no mínimo 60\% desses recursos devem ser utilizados na remuneração dos profissionais do magistério, técnicos das áreas de administração ou direção escolar, supervisão, orientação educacional, planejamento e inspeção escolar, em efetivo exercício no ensino fundamental público. Com isso, a lei procura garantir uma melhoria na remuneração de tais profissionais. $^{23} \mathrm{O}$ restante dos recursos do Fundo (máximo de 40\%) deve ser aplicado em outras ações de manutenção e desenvolvimento desse nível de ensino. ${ }^{24}$ Também a aplicação dos recursos do Fundef está sujeita à fiscalização de um conselho com participação da sociedade civil. Cada Estado e cada município deve ter um Conselho de Acompanhamento e Controle Social do FUNDEF, com a atribuição de supervisionar mensalmente a repartição, a transferência e a aplicação dos recursos do Fundo pelo respectivo ente federativo, bem como a realização do Censo Escolar anual..$^{25}$

Como último exemplo de conselho com participação da sociedade civil encarregado de fiscalizar os poderes públicos, podemos citar o Conselho de Gestão Fiscal, criado pela Lei de Responsa-

${ }^{23}$ Cf. o site do Ministério da Educação, <http://www.mec.gov.br>, agosto de 2002, entre dezembro de 1997 e junho de 2000, o aumento médio na remuneração dos professores foi de $29.6 \%$, com destaque para algumas regióes, como a nordeste, onde os docentes do ensino fundamental foram beneficiados com um aumento médio de 59.6\%, aí incluídas as redes municipais e estaduais.

${ }^{24}$ Cf. o site do Ministério da Educação, <http://www.mec.gov.br>, agosto de 2002, essas 'ações' abrangem a aquisição, manutenção e utilização de instalações e equipamentos necessários ao ensino; a remuneração e o aperfeiçoamento dos profissionais da educação; a aquisição de material didático; o transporte escolar.

${ }^{25} \mathrm{Cf}$. Lei $9424 / 96$ : art. $4^{\circ}, \mathbb{S} 1^{\circ}$, II-IV, nos Estados, o conselho será formado por no mínimo sete membros, representando respectivamente: i) o Poder Executivo Estadual; ii) os poderes Executivos Municipais; iii) o Conselho Estadual de Educação; iv) os pais de alunos e professores das escolas públicas do ensino fundamental; v) a seccional da união nacional dos dirigentes municipais de educação; vi) a seccional da Confederação Nacional dos Trabalhadores em Educação; vii) a Delegacia Regional do Ministério da Educação e do Desporto. No DF o conselho será composto por no mínimo cinco membros, sendo as representações as previstas para o âmbito estadual, salvo as indicadas nas alíneas $b$, e e $g$. Nos municípios, o conselho será constituído por no mínimo quatro membros (ou cinco, caso haja Conselho Municipal de Educação) representando respectivamente: i) a Secretaria Municipal de Educação ou órgão equivalente; ii) os professores e os diretores das escolas públicas do ensino fundamental; iii) os pais de alunos; iv) os servidores das escolas públicas do ensino fundamental. 
bilidade Fiscal (art. 67), e formado por representantes de todos os poderes e esferas de governo, do MP e de entidades técnicas representativas da sociedade, visando à harmonização e coordenação entre os entes da federação; disseminação de práticas que resultem em maior eficiência na alocação e execução do gasto público, na arrecadação de receitas, no controle do endividamento e na transparência da gestão fiscal; adoção de normas de consolidação das contas públicas, padronização das prestações de contas e dos relatórios e demonstrativos de gestão fiscal, adoção de normas e padrões mais simples para os pequenos municípios, bem como outros, necessários ao controle social; divulgação de análises, estudos e diagnósticos.

A respeito das formas de controle social da administração pública, deve ser sempre lembrado que elas também não estão imunes à contaminação de suas finalidades por interesses patrimonialistas e criminosos, principalmente nas instâncias locais de governo, onde as redes de poder informais podem criar laços com os cidadãos nos próprios bairros em que moram. ${ }^{26}$ Isso, contudo, não quer dizer que sempre haverá tal desvio de finalidade. Muitas vezes esses 'laços' são devidos mais à força do que à vontade, principalmente nos bairros mais carentes das grandes metrópoles, onde por vezes certas áreas são controladas pelo crime organizado que promove o tráfico ilícito de entorpecentes e de armas. O fato de serem tais relações 'impostas' ao invés de negociadas, não quer dizer que as atividades de fiscalização popular direta e de controle social dos poderes públicos (inclusive por meio dos conselhos referidos) também serão contaminadas. Nesse processo social tenso, a política pública que mais sofre deturpação é a política de segurança, inclusive porque o crime organizado por vezes se alia a membros das polícias civil (que faz a investigação de crimes) e militar (que faz a segurança ostensiva). Nas demais políticas públicas de efetivação da cidadania, é possível que não haja interferência no controle social exercido sobre a administração pública, o que de forma alguma significa que podemos compactuar com a situação atual, mas apenas indica que podemos acreditar no desenvolvimento das formas de controle social dos poderes públicos, mesmo nas áreas mais carentes das grandes metrópoles.

\footnotetext{
${ }^{26}$ A esse respeito merece ser lembrada a pesquisa feita pela Assembléia Legislativa do Estado do Rio de Janeiro, divulgada no Jornal O Globo (2002: 22), estimando que cerca de 400 dirigentes comunitários estão associados ao Tráfico Ilícito de Entorpecentes. O mesmo artigo diz ainda que alguns traficantes chegam a dizer a líderes comunitários das favelas sob seu comando que ofereçam votos dos moradores a políticos.
} 


\section{Considerações finais}

Desde a promulgação da atual Constituição Federal em 1988, têm aumentado consideravelmente as formas de participação popular junto à administração pública, as quais aos poucos passam a promover uma renovação da cultura de nosso país, uma cultura que passa a estar mais voltada para o respeito dos poderes públicos aos direitos de cidadania, mais inteirada acerca das 'coisas da política', mais preocupada com valores comunitários, sendo crucial no processo de descentralização das políticas públicas de efetivação dos direitos de cidadania, o qual tem ocorrido desde a redemocratização do País.

Ainda há muito o que mudar, todavia. Se nos municípios as experiências de participação popular tem sido mais freqüentes, nos níveis mais abrangentes de governo, principalmente na esfera federal, a participação da sociedade ainda é incipiente no tocante a políticas públicas de educação e saúde, por exemplo, a uma, porque nossa sociedade civil ainda é pouco organizada, e a duas, porque há um número considerável de pessoas, seja nas grandes cidades, seja nas cidades do interior, que estão impossibilitadas de participar das formas de controle social do Estado, pelas mais variadas razões: i) pelas restrições ao direito de ir e vir dos cidadãos, principalmente em espaços urbanos específicos dominados por organizações criminosas; ii) pelas relações de poder patrimonialistas e coronelistas que são mantidas até hoje, principalmente nas cidades interioranas de nossas regiões nordeste e norte, mas que ainda permanecem nas demais regiões; iii) pelas dificuldades quotidianas, como o desemprego, que impulsionam os cidadãos para os mais variados trabalhos, reduzindo sua vida ao binômio trabalho/família; iv) pela baixa escolaridade e cultura geral de nossos cidadãos, pois que muitos sequer têm noção acerca de seus direitos.

Outro aspecto relevante sobre o controle social, está na publicidade da atuação estatal. Se não há transparência na gestão da coisa pública, a sociedade tem mais dificuldade para fiscalizála. E não basta que os governos disponibilizem a todos informações sobre as despesas públicas e sobre a execução dos programas de governo, conforme determinam a Constituição Federal e a Lei de Responsabilidade Fiscal, não basta que sejam realizadas audiências públicas para se discutirem questões relevantes para a sociedade. Os dados divulgados devem ser confiáveis e de fácil entendimento, de forma que a população possa compreender os pontos em discussão e se posicionar. Assim, transparência 
não pressupõe apenas publicidade, mas sim 'acesso fácil ao significado das informações divulgadas'.

Como visto, existem outras formas de controle do Estado, além daquele que é exercido pela sociedade. O controle exercido pelos Parlamentos, pelos Tribunais de Contas, pelo Poder Judiciário e pelo Ministério Público, além do controle interno das próprias entidades administrativas, são cruciais para a eficiência de todo o sistema. É justamente pela conjugação das diversas formas de controle da administração pública que as eventuais falhas de uma modalidade podem ser supridas pela atuação de outra.

Ao falarmos sobre o controle externo exercido pelo Ministério Público, pelo Poder Judiciário, pelos Tribunais de Contas e pelo Poder Legislativo, é necessário lembrar que só neste último caso observa-se a autonomia entre os entes federados, uma vez que cada um tem o seu próprio Poder Legislativo. Nos demais, o município pode sair 'prejudicado', pois as instituições que farão o controle são da estrutura de outro ente federado -os municípios não possuem Poder Judiciário, nem Ministério Público e, salvo raras exceções, nem Tribunal de Contas. ${ }^{27}$ Assim, pode ser, por exemplo, que em uma questão ambiental, de competência comum, o Ministério Público responsabilize mais facilmente o município, do que o Estado ou a União, pois sua atuação para responsabilizar o executivo estadual ou federal poderá influenciar no funcionamento da instituição dentro de um contexto político-administrativo presente. Ou ainda, pode ser que a Lei de Responsabilidade Fiscal seja mais fiscalizada pelos Tribunais de Contas (estaduais) com relação aos municípios do que com relação aos Estados. De qualquer forma, devemos lembrar que esse tipo de atuação tendenciosa é ilegal e deve ser repelida pela sociedade. Ao menos no caso do Ministério Público (e o mesmo se pode dizer do Poder Judiciário, em regra), ela dificilmente será observada ou aceita por seus membros. As instituições que exercem o controle externo da administração pública detém autonomia administrativa e financeira, e seus membros, independência funcional, justamente para que possam exercer suas funções sem favoritismos ou perseguições, de forma isenta, impondo o cumpri-

${ }^{27}$ Somente os municípios de São Paulo e Rio de Janeiro têm Tribunal de Contas próprio, os demais municípios têm suas contas aprovadas pelo Tribunal de Contas dos Estados, ou por um 'Tribunal de Contas Municipais', mas que integra a organização do Estado federado. Nesse caso, a autonomia municipal fica prejudicada, mas isso decorre do Texto Constitucional (art. $31, \mathbb{S} 4^{\circ}$ ) que vedou expressamente a criação de novos Tribunais de Contas no âmbito dos municípios a partir da promulgação da Constitução Federal em 1988. 
mento da Constituição e das leis a todos os agentes públicos, seja qual for sua esfera federativa.

Lembre-se que dentre as várias formas de controle do Estado, o controle social é o que guarda o maior potencial de trazer eficiência ao sistema, pois como diria Ferdinand Lassale, o povo guarda o maior de todos os poderes do Estado: os cidadãos comuns estão em toda parte, aos milhões, enquanto as autoridades e agentes públicos contam-se facilmente. O povo, contudo, é desorganizado, e por isso dominado por outras formas de poder, que são mais fortes porque são organizadas (Lassale, 1969: 71-72). Por vezes as lideranças comunitárias acabam se aliando a grupos com interesses patrimonialistas/clientelistas, ou pior, a grupos ligados ao crime organizado, o que demonstra que nossa cultura de cidadania ainda está no início de seu desenvolvimento, e ainda não se espalhou por todos os setores sociais.

Em face dessas circunstâncias, e das deficiências observadas em outras formas de controle do Estado, ressalta a importância das funções do Ministério Público no processo de mudança de nossa sociedade civil. Na medida que o controle das políticas públicas pela sociedade for se tornando prática cultural em nosso povo, o que é essencial em um Estado dito democrático, como o nosso, a tendência é de que alguns espaços de atuação hoje ocupados pelo Ministério Público sejam compartilhados com essa nova sociedade civil organizada, possibilitando ao MP concentrar seus esforços em áreas em que só ele pode atuar. Além disso, é provável que outras formas de controle se aperfeiçoem, como por exemplo, o exercido pelos Tribunais de Contas. Os resultados a serem progressivamente alcançados abrangem uma maior eficiência nas políticas públicas de atendimento aos direitos de cidadania e a redução das desigualdades sociais.

Durante esse "processo de transição" de nossa sociedade, quando o Parlamento estiver tomado por disputas entre lobbies e oligarquias coronelistas; quando os membros dos Tribunais de Contas se recusarem a exercer suas funções técnicas, e cederem à pressões de seus grupos políticos de origem; quando o controle interno da administração pública for ausente, vagaroso ou conivente ante a ilegalidades; quando o controle social for corrompido, coagido ou inexistente, resta sempre a possibilidade de que o Ministério Público promova (inclusive judicialmente) a correção das ilegalidades cometidas, uma vez que seus membros têm o poder (e o dever) de atuar, independentemente de provocação, como guardiães do direito e da sociedade. 


\section{Bibliografia}

Banco Nacional de Desenvolvimento Econômico e Social, <http:/ /www.federativo.gov.br>, agosto de 2002.

Asensio, Miguel A. (2000), Federalismo fiscal. Fundamentos, análisis comparado y el caso argentino, Ed. Ciudad Argentina, Buenos Aires.

Brito, Carlos Ayres (2002), "O regime constitucional dos Tribunais de Contas”, Revista Interesse Público, 13, Editora Notadez, Sapucaia do Sul, RS, Brasil, pp. 177-187.

Fernandes, Flávio Sátiro (1995), "Prestação de Contas - instrumento de transparência da Administração", Revista do Tribunal de Contas do Estado do Pará, 44, Tribunal de Contas do Estado do Pará, Belém, pp. 193-205.

Fernandes, Jorge Ulisses Jacoby (1999), “Os limites do poder fiscalizador do Tribunal de Contas do Estado", Revista do Tribunal de Contas do Distrito Federal, 25 (1), Tribunal de Contas do Distrito Federal, Brasília, pp. 71-107.

Fundo Nacional de Desenvolvimento da Educação, < http:// www.fnde.gov.br>, agosto de 2002.

Instituto de Pesquisa Econômica Aplicada (2002), Dados macroeconômicos e regionais en $<$ http://www.ipeadata.gov.br $>$, agosto de 2002.

Jornal do Ministério da Educação, ano Xv, nº 20, Brasília/DF, agosto de 2002 , p. 5 .

Jornal O Globo (2002), “Grampo revela lobby eleitoral de Uê: em ligações, trafiacante preso manda oferecer votos de favelas a candidatos”, Rio de Janeiro, 05/07/02, p. 22.

Lassale, Ferdinand (1969), O que é uma Constituição, Laemmert, Rio de Janeiro.

Mazzilli, Hugo Nigro (2001), Regime Jurídico do Ministério Público, $5^{\text {a }}$ edn., Saraiva, São Paulo. 
Medauar, Odete (2002), Direito Administrativo Moderno, $6^{\mathrm{a}}$ edn., RT, São Paulo.

Meirelles, Hely Lopes (2002), Direito Administrativo Brasileiro, $27^{\mathrm{a}}$ edn., Malheiros, São Paulo.

Ministério da Educação (2002), en <http://www.mec.gov.br>, agosto de 2002.

Moreira Neto, Diogo de Figueiredo (2001), "Algumas notas sobre órgãos constitucionalmente autônomos: um estudo de caso sobre os Tribunais de Contas no Brasil", Revista de Direito Administrativo, 223, Renovar, Rio de Janeiro, pp. 01-24.

Revista Veja (2001), "Quase parando: Brindeiro tem 4514 processos na gaveta e -incrível- quer um quarto mandato", São Paulo, 06/06/2001, pp. 125-126.

Revista Veja (2002), "Quando o mau exemplo vem de cima: conselheiros de tribunais de contas são acusados de fazer o que deveriam impedir", São Paulo, 16/01/2002, pp. 36-39.

Santos, Angela M. P. (2003), "Municípios como atores das políticas públicas”, em Angela M. P. Santos, Economia, Espaço e Sociedade no Rio de Janeiro, FGV, Rio de Janeiro.

Santos, Boaventura de Souza (2002), "Orçamento participativo em Porto Alegre: para uma democracia redistributiva”, em Boaventura de Souza Santos (org.), Democratizar a Democracia: os caminhos da democracia participativa, Série Reinventar a emancipação social: para novos manifestos, vol. 1, Civilização Brasileira, Rio de Janeiro, pp. 455-559.

Sauwen Filho, João Francisco (1999), O Ministério Público Brasileiro e o Estado Democrático de Direito, Renovar, Rio de Janeiro.

Enviado: el 30 de junio de 2003. Aceptado: 28 de noviembre de 2003. 